\title{
APLIKASI BIOPESTISIDA Streptomyces sp. DALAM MENGENDALIKAN PENYAKIT PADA TANAMAN KENTANG (Solanum tuberosum L.) DI DATARAN MEDIUM
}

\section{APPLICATION OF BIOPESTICIDES STREPTOMYCES SP. IN CONTROLLING DISEASE IN POTATO (SOLANUM TUBEROSUM L.) PLANTS IN THE MEDIUM PLAIN}

\author{
Ni Made Dini Widia Handayani ${ }^{1}$, Irwan Muthahanas ${ }^{1}$, Aluh Nikmatullah ${ }^{1 *}$ \\ ${ }^{1}$ Program Studi Agroekoteknologi Fakultas Pertanian Universitas Mataram, Mataram, Indonesia \\ *Email Penulis Korespondensi:aluh_nikmatullah@unram.ac.id
}

\begin{abstract}
Abstrak
Tujuan penelitian untuk mengetahui efektifitas biopestisida Streptomyces sp. dalam mengendalikan penyakit pada tanaman kentang di dataran medium. Penelitian dilaksanakan di Laboratorium Mikrobiologi Fakultas Pertanian Universitas Mataram dan di UPB BBI Desa Santong Kecamatan Kayangan Kabupaten Lombok Utara NTB, bulan Oktober 2016 sampai dengan Maret 2017. Metode penelitian yaitu eksperimental. Rancangan penelitian uji in-vitro menggunakan Rancangan Acak Lengkap dengan 5 perlakuan pada 2 jenis patogen ( $S$. rolfsii dan Fusarium sp.) diulang 3 kali diperoleh 30 unit percobaan. Uji in-vivo menggunakan rancangan petak terbagi (Split Plot Design) dengan varietas kentang sebagai faktor utama Mikaraset (P1), Atlantic (P2), Bliss (P3) yang ditata dalam RAK diulang 3 kali dan uji lama perendaman umbi benih kentang dengan Streptomyces sp. (tanpa perendaman (S0), 30 menit (S1), 40 menit (S2), 50 menit (S3), dan 60 menit (S4) sebagai anak petak diperoleh 45 unit percobaan. Hasil menunjukan Streptomyces isolat $\mathrm{BSi}$ memberikan kemampuan terbaik dalam menghambat jamur patogen $S$. rolfsii dan Fusarium sp. dalam uji in-vitro. Jamur patogen yang menyerang tanaman kentang yaitu $P$. infestans dan Fusarium sp. Perlakuan (S4) dan varietas (P3) paling efektif menunda masa inkubasi, menekan persentase dari serangan patogen P. infestans dan Fusarium sp.. Interaksi terbaik dalam menunda masa inkubasi penyakit terdapat pada perlakuan perendaman selama 60 menit $\left(\mathrm{S}_{4}\right)$ dengan varietas Blis $\left(\mathrm{P}_{3}\right)$. Perlakuan varietas benih kentang dengan perendaman biopestisida Streptomyces sp. selama 60 menit $\left(\mathrm{S}_{4}\right)$ menghasilkan jumlah umbi per tanaman, jumlah umbi per petak, berat per umbi dan berat umbi per petak tertinggi. Varietas Blis $\left(\mathrm{P}_{3}\right)$ menghasilkan jumlah umbi per tanaman, jumlah umbi per petak, dan berat umbi per petak tertinggi, dan varietas Mikraset menghasilkan berat satuan umbi tertinggi. Adapun interaksi terbaik antara varietas Atlantik (P2) dengan lama perendaman biopestisida Streptomyces sp. isolat BSi selama 60 menit $\left(\mathrm{S}_{4}\right)$ dan varietas $\mathrm{Blis}\left(\mathrm{P}_{3}\right)$ dengan lama perendaman biopestisida Streptomyces sp. isolat BSi selama 60 menit $\left(\mathrm{S}_{4}\right)$ menghasilkan berat umbi per petak tertinggi.

Kata Kunci: Kentang, Varietas, Streptomyces sp, P.infestans, Fusarium sp.
\end{abstract}

\section{Abstract}

The purpose of this research is to know the effectiveness of biopesticide Streptomyces sp. In controlling disease in potato plants in the medium plains. The research was conducted in Microbiology Laboratory of Faculty of Agriculture University of Mataram and at UPB BBI Santong Village District Kayangan, North Lombok NTB, October 2016 until March 2017. The research method is experimental. In-vitro test design using Completely Randomized Design with 5 treatments on 2 pathogen species $(S$. rolfsii and Fusarium sp.) Was repeated 3 times obtained 30 experimental units. In-vivo test using Split Plot Design with potato varieties as the main factor of Mikaraset (P1), Atlantic (P2), Bliss (P3) arranged in RAK was repeated 3 times and old test of potato seed immersion with Streptomyces sp . (S0), 30 minutes (S1), 40 minutes (S2), 50 minutes (S3), and 60 minutes (S4) as plots were obtained 45 experimental units The results showed Streptomyces isolate BSi gave the best ability to inhibit the fungus Pathogen S. rolfsii and Fusarium sp in in vitro tests Pathogenic fungi that attack potato plants ie P. infestans and Fusarium sp. Treatment (S4) and variety (P3) most effectively delay incubation period, suppress the percentage of pathogen attack P. Infestans and Fusarium sp .. The best interaction in delaying incubation period was found in 60 minutes (S4) immersion treatment with Blis variety (P3) .The treatment of potato seed varieties by immersion of biopestiside Streptomyces sp for 60 minutes (S4) 
resulted in the number of tubers per Crops, number of tubers per plot, weight per tuber and weight of tubers per highest plot Blis varieties (P3) yielded the number of tubers per plant, number of tubers per plot, and weight of tubers per highest plot, and varieties Mikraset $m$ Produce the highest unit weight of tuber. The best interaction between Atlantic varieties (P2) with the long immersion of biopesticide Streptomyces sp. Isolate BSi for 60 minutes (S4) and Blis varieties (P3) with long immersion of biopesticide Streptomyces sp. BSi isolate for 60 minutes (S4) yields the highest tuber weight per plot Keywords: Potato,Varieties, Streptomyces sp., Phytopthora infestans, Fusarium sp.

\section{PENDAHULUAN}

Kentang ( $S$. tuberosum L.) merupakan salah satu jenis tanaman penting di Indonesia setelah gandum, jagung dan padi. Meskipun kentang bukan makanan pokok bagi rakyat Indonesia, akan tetapi setiap tahun permintaan akan kentang meningkat. Wattimena (2006) menyatakan varietas kentang yang dibutuhkan di Indonesia yaitu dapat beradaptasi dengan permasalah lingkungan baik secara fisik maupun biologi, sesuai dengan manfaatnya baik untuk diolah ataupun non olahan, sesuai dengan hari pendek di Indonesia dan tahan terhadap serangan OPT maupun penyakit. Meningkatnya permintaan kentang seiring dengan bertambahnya jumlah penduduk, taraf hidup masyarakat yang meningkat serta banyaknya penduduk luar ataupun wisatawan asing yang ke Indonesia. Khususnya di daerah Nusa Tenggara Barat (NTB) produksi tanaman kentang mengalami penurunan dari tahun 2012 yaitu dari 6.526 ton menjadi 4.056 ton pada tahun 2013. Hal tersebut dikarenakan lahan tempat produksi kentang di NTB yaitu hanya berpusat di dataran tinggi Lombok Timur. Berkurangnya lahan produksi kentang yaitu dari 337 ha pada tahun 2012 menjadi 242 ha pada tahun 2013 (Badan Pusat Statistik Provinsi Nusa Tenggara Barat, 2014).

Terbatasnya lahan yang cocok (dataran tinggi) dan berbagai upaya konservasi pada dataran tinggi guna mencegah longsor menyebabkan lahan untuk pertanaman kentang menjadi terbatas dan merupakan kendala untuk meningkatkan produksi kentang. Oleh sebab itu di daerah Lombok perlu dilakukan usaha untuk mengembangkan budidaya tanaman kentang ke dataran yang lebih rendah (medium) yaitu 300-700 m dpl untuk menambah daerah produksi kentang. Jumlah luas daerah dataran medium di Lombok terbilang cukup luas sehingga mempunyai prospek yang baik kedepannya untuk dijadikan area pertanaman kentang. Seiring penanaman kentang di dataran medium muncul kendala lain yaitu mendapatkan benih yang tahan terhadap serangan penyakit. Penanaman kentang di dataran medium akan dihadapkan dengan kendala suhu tinggi, yang dapat menjadi faktor penghambat pembentukan umbi. Pengendalian penyakit yang terjadi pada tanaman kentang tersebut seringkali menggunakan fungisida sintetik yang memiliki bahan aktif tertentu yang dapat membunuh jamur. Aplikasi fungisida sintetis dapat berdampak negatif bagi kesehatan pengguna dan tercemarnya air, tanah, udara. Oleh karena itu diperlukanya alternatif lain dalam pengendalian penyakit tersebut, seperti menggunakan biopestisida dari agen hayati yaitu Streptomyces sp.

Salah satu mikroba antagonis yang berasal dari bakteri yang dapat menghasilkan antibiotik yaitu Streptomyces sp.. Streptomyces sp. merupakan salah satu kelompok mikroorganisme antagonis yang berpotensi digunakan sebagai agens pengendali hayati patogen penyebab penyakit tanaman. Beberapa peneliti melaporkan kemampuan Streptomyces sp. sebagai agen pengendali patogen penyebab penyakit pada tanaman diantaranya Muthahanas et al (2008), menyatakan bahwa kemampuan isolat Streptomyces sp. menghamabat jamur patogen tanaman berbeda-beda. Isolat BSi mampu menghambat jamur $F$. oxysporum, Rhizoctonia solani, dan S. rolfsii. 
Berdasarkan uraian diatas maka peneliti menyusun sebuah penelitian terkait dengan aplikasi biopestisida Streptomyces sp. dalam mengendalikan penyakit pada tanaman kentang (S. tuberosum L.) di dataran medium. Tujuan dari penelitian ini yaitu untuk mengetahui efektifitas biopestisida Streptomyces sp. dalam mengendalikan penyakit pada tanaman kentang di dataran medium.

\section{METODE PENELITIAN}

\section{Tempat dan Waktu}

Penelitian ini dilaksanakan di Laboratorium Mikrobiologi Fakultas Pertanian Universitas Mataram dan di Unit Produksi Balai Benih Induk Desa Santong Kecamatan Kayangan Kabupaten Lombok Utara NTB. Pelaksanaan dimulai pada bulan Oktober 2016 sampai dengan Maret 2017.

\section{Metode Penelitian}

Metode penelitian yang digunakan dalam penelitian ini adalah metode eksperimental.

\section{Rancangan Penelitian}

Uji in-vitro di Laboratorium Mikrobiologi Fakultas Pertanian Universitas Mataram. Rancangan yang digunakan adalah RAL (Rancangan Acak Lengkap) yang terdiri 5 perlakuan, masing-masing 2 patogen diulang sebanyak 3 kali sehingga diperoleh 30 unit percobaan. Uji in-vivo menggunakan rancangan petak terbagi (Split Plot Design) dengan faktor varietas kentang sebagai petak utama $\left(\mathrm{P}_{1}, \mathrm{P}_{2}, \mathrm{P}_{3}\right)$ yang ditata dalam RAK (Rancangan Acak Kelompok) yg diulang 3 kali dan uji aplikasi lama perendaman umbi benih kentang dengan Streptomyces sp. isolat BSi $\left(\mathrm{S}_{0}, \mathrm{~S}_{1}, \mathrm{~S}_{2}, \mathrm{~S}_{3}\right.$ dan $\left.\mathrm{S}_{4}\right)$ sebagai anak petak sehingga diperoleh 45 unit percobaan.

\section{Bahan Percobaan}

Bahan-bahan digunakan adalah media YMA, media PDA, isolat Fusarium oxysporum, isolat $S$. Rolfsii, beberapa jenis isolat Streptomyces sp. (Gi, IMi, BSc, dan BSi), aquades, alkohol, molase, formulasi cair untuk Streptomyces sp., kertas label, kertas saring steril, empat varietas benih kentang (Mikraset, Atlantis, Blis), pupuk SP 36, pupuk urea, KCL dan organik.

\section{Alat Percobaan}

Alat-alat yang digunakan adalah cawan Petri, erlenmeyer, lampu bunsen, korek api, microwave, pinset, jarum ent, baker glas, laminar air flow, autoclave, timbangan analitik, shaker, gelas ukur, cangkul, sprayer, ajir dan ember.

\section{Pelaksanaan Penelitian}

\section{Pembuatan Media}

a. Media YMA (Yeast Manitol Agar)

b. Media PDA (Potato Dextrose Agar)

c. Media Molases

\section{Penumbuhan Agen Antagonis dan Jamur Patogen}

Isolat Streptomyces spp. (Gi, BSi, BSc dan IMi) di peroleh dari koleksi pribadi Bapak Ir. Irwan Muthahanas, M.Si. Isolat ditumbuhkan dan diperbanyak pada medium YMA (Yeast Manitol Agar) yang digunakan sebagai inokulum dalam perobaan in-vitro dan in-vivo. Isolat jamur $S$. Rolfsii di peroleh dari koleksi mahasiswi Bq. Anisa K. Sedangkan isolat jamur Fusarium oxysporum diperoleh dari koleksi Bapak Ir. Irwan Muthahanas, M.Si. Isolat $S$. rolfsii dan Fusarium oxysporum ditumbuhkandan diperbanyak pada medium PDA yang digunakan sebagai inokulum dalam percobaan invitro dan in-vivo. 


\section{Pelaksanaan Percobaan in-vitro}

Pengujian in-vitro pada masing-masing agen antagonis dilakukan dengan cara meletakkan plug agen antagonis secara berdampingan dengan plug isolat dalam cawan petri. Pengamatan dilakukan pada hari ke 3 setelah pengujian dilakukan. Pengamatan daya hambat dilakukan dengan cara mengukur jari-jari koloni jamur yang terdekat dan terjauh dari kedua bahan uji tersebut. Dilakukan perhitungan dengan rumus sebagai berikut:

$\mathrm{X}=\frac{r 1-r 2}{r 1} \mathrm{X} 100 \%$

Keterangan:

$\mathrm{X}=$ Persentase daya hambat

r1 = Diameter koloni jamur patogen pada kontrol

r2 = Diameter koloni jamur patogen pada perlakuan

4. Pembuatan Formulasi Cair Antibiotik Streptomyces sp.

Streptomyces sp. isolat BSi memberikan kemampuan terbaik dalam menghambat patogen S. Rolfsii dan Fusarium sp. yang diuji secara in-vitro. Setelah ditemukan hal tersebut kemudian dilakukan penumbuhan pada medium YMA (Yeast Manitol Agar), BSi yang tumbuh diambil dengan menggunakan jarum ose aseptis, kemudian di masukkan ke dalam Erlenmeyer $200 \mathrm{ml}$ berisi cairan molase (2\%) steril. Bejana Erlenmeyer selanjutnya di gojok dengan menggunakan orbital shaker dengan kecepatan $150 \mathrm{rpm}$, selama 7 hari. Sel yang diperoleh diamati di bawah mikroskop kemudian dihitung kerapatannya. Kerapatan yang akan digunakan adalah $1 \times 10^{5} \frac{\mathrm{konidia}}{\mathrm{mL}}$.

\section{Uji in-vivo}

a) Persiapan Lahan

Lahan dibajak sampai gembur agar perkembangan lahan dan pembesaran umbi berlangsung optimal. Sebelum dibuat guludan lahan didiamkan terlebih dahulu selama 2 minggu.

b) Pengolahan Lahan

Bedengan dibuat memanjang kearah utara-selatan agar mendapatkan sinar matahari secara optimal, dengan lebar guludan $70 \mathrm{~cm}$, tinggi bedengan $30 \mathrm{~cm}$ dan jarak antar guludan $30 \mathrm{~cm}$. Sekeliling guludan dibuat saluran pembuangan air agar tanamnan kentang (Solanum tuberosum L.) tidak tergenang dan lembab.

c) Persiapan dan Perlakuan Benih

Benih varietas Mikraset $\left(\mathrm{P}_{1}\right)$, Atlantik $\left(\mathrm{P}_{2}\right)$, dan Blis $\left(\mathrm{P}_{3}\right)$ direndam dengan cairan molases suspensi Streptomyces sp. Isolat BSi, dengan periode waktu sebagai berikut:

$$
\begin{aligned}
& \mathrm{S}_{0}=\text { Tanpa perlakuan } \\
& \mathrm{S}_{1}=30 \text { menit } \\
& \mathrm{S}_{2}=40 \text { menit } \\
& \mathrm{S}_{3}=50 \text { menit } \\
& \mathrm{S}_{4}=60 \text { menit }
\end{aligned}
$$

\section{d) Penanaman}

Benih yang yang telah diberi perlakukan, ditanam dengan sistem larikan dengan jarak tanamnya $70 \mathrm{~cm}$ x $30 \mathrm{~cm}$ pada lubang tanam dengan kedalaman $5 \mathrm{~cm}$. BENIH dimasukkan kedalam lubang tanaman dan kemudian ditutup dengan tanah.

e) Penyiangan

Penyiangan dimulai pada saat tanaman berumur 14 HST dan selanjutnya dilakukan apabila pertumbuhan dari gulma dirasa mulai mengganggu tanaman kentang. f) Pemupukan 
Pemupukan dasar tanaman kentang ( $S$, tuberosum L.) dilaksanakan sebelum penanaman kentang menggunakan pupuk SP-36 $100 \mathrm{~kg} / \mathrm{ha}$, pupuk urea $100 \mathrm{~kg} / \mathrm{ha}$, pupuk KCL $50 \mathrm{~kg} / \mathrm{ha}$ dan pupuk organik 1,5 ton/ha. Pemupukan susulan menggunakan pupuk SP-36 $200 \mathrm{~kg} / \mathrm{ha}$, pupuk urea $150 \mathrm{~kg} / \mathrm{ha}$, pupuk KCL $50 \mathrm{~kg} / \mathrm{ha}$ dan pupuk organik 1,5 ton/ha

\section{g) Pengairan}

Kentang (S. tuberosum L.) sangat peka terhadap kekurangan dan kelebihan air oleh karena itu perlu adanya pengairan yang terkontrol, pengairan tanaman kentang ( $S$. tuberosum L.) dilakukan apabila tidak terjadi hujan karena dilakukan diluar musim tanam atau ditanaman pada musim penghujan.

\section{Variabel Pengamatan}

\section{a. Masa Inkubasi}

Masa inkubasi yang mulai terhitung sejak sehari setelah tanam sampai dengan tampak gejala pertama.

b. Insiden Penyakit

Pada penelitian ini infeksi yang terjadi pada setiap tanaman dinyatakan sebagai suatu insidensi penyakit, kemudian jumlah tanaman yang terinfeksi pada setiap perlakuan dihitung dan selanjutnya dinyatakan dalam bentuk persentase terhadap total tanaman. Insiden penyakit dihitung dengan rumus sebagai berikut:

$$
\mathrm{IP}=\frac{a}{a+b} \quad \mathrm{X} 100 \%
$$

Keterangan :

IP = Insiden Penyakit

$\mathrm{a}=$ Jumlah tanaman sakit bergejala yang diamati

$\mathrm{b}=$ Jumlah tanaman sehat yang diamati

\section{c. Identifikasi Penyakit}

Pada penelitian ini dilakukan identifikasi terhadap patogen tanaman yang diduga menjadi penyebab terjadinya serangan penyakit tanaman.

\section{d. Hasil atau Produksi}

Pengamatan pada data produksi yaitu meliputi umur panen, jumlah umbi pertanaman, berat perumbi, ukuran umbi, berat total umbi per petak, dan jumlah umbi perpetak.

e. Analisis Hasil

Data hasil pengamatan dianalisis dengan menggunakan analisis keragaman pada taraf nyata $5 \%$ dengan menggunakan program software minitab. Apabila terdapat perlakuan yang berbeda nyata, maka dilakukan uji lanjut dengan Beda Nyata Jujur (BNJ) pada taraf 5\%.

\section{HASIL DAN PEMBAHASAN}

\section{Uji in-vitro}

Persentase daya hambat yang dimiliki oleh keempat isolat Streptomyces sp. dalam menekan patogen $S$. rolfsii masing-masing sebesar 28,9\% (Gi), 27,8\% (BSc), 58,9\% (BSi) dan 16,7\% (IMi). Daya hambat pada patogen Fusarium sp. masing-masing sebesar 26,7\% (Gi), 5,6\% (BSc), 60,0\% (BSi) dan 30,0\% (IMi) (Tabel 1.). Hal tersebut menunjukan isolat BSi memiliki daya hambat tertinggi pada kedua jenis patogen, masing-masing sebesar 58,89\% untuk S. rolfsii dan 60,00\% untuk Fusarium sp. Hal ini menunjukan kemampuan dari keempat isolat Streptomyces sp. berbeda dalam 
menghambat pertumbuhan patogen tersebut. Diduga karena keempat isolat Streptomyces sp. memiliki dan menghasilkan senyawa metabolit sekunder yang berbeda dan keragaman senyawa bioaktif yang dimiliki berbeda untuk setiap jenisnya. Menurut pendapat Pathania dan Brown, 2008 dalam Hidayat (2017) senyawa antibiotik yang dihasilkan akan menunjukan aktivitas toksisitas selektif dan akan menumngkinkan terjadi perbedaan pada tiap organisme.

Tabel 1. Nilai Rata-Rata Daya Hambat Isolat Streptomyces sp. Terhadap Patogen Penyakit S. rolfsii dan Fusarium sp.

\begin{tabular}{cccc}
\hline Perlakuan & $\begin{array}{c}\text { Daya Hambat } \\
\text { S. rolfsii }(\%)\end{array}$ & Perlakuan & $\begin{array}{c}\text { Daya Hambat } \\
\text { Fusarium } \text { sp. }(\%)\end{array}$ \\
\hline Kontrol & 0,0 c & Kontrol & 0,0 c \\
S vs Gi & 28,9 b & F vs Gi & 26,7 b \\
S vs BSc & 27,8 bc & F vs BSc & 5,6 bc \\
S vs BSi & 58,9 a & F vs BSi & 60,0 a \\
S vs IMi & 16,7 bc & F vs IMi & 30,0 b \\
\hline BNJ 5\% & 28,9 & BNJ 5\% & 26,9 \\
\hline
\end{tabular}

${ }^{*}$ : Angka-angka yang diikuti oleh huruf yang sama pada kolom yang sama menunjukan tidak berbeda nyata menurut uji BNJ 5\%

\section{Uji in-vivo}

Hasil uji in-vitro didapatkan Streptomyces sp. isolat BSi yang memiliki kemampuan paling baik dalam menekan pertumbuhan jamur patogen penyebab penyakit $S$. rolfsii dan Fusarium sp.. Berdasarkan hal tersebut isolat BSi digunakan sebagai agen hayati biopestisida dalam menekan penyakit kentang di dataran medium. Uji in-vivo menunjukan hasil perlakuan tanpa perendaman benih kentang $\left(\mathrm{S}_{0}\right)$ memiliki masa inkubasi paling cepat yaitu dengan waktu 33,0 HST. Hal tersebut tidak berbeda nyata dengan perlakuan perendaman benih kentang selama 30 menit $\left(S_{1}\right)$ yaitu 40,0 HST. Masa inkubasi terlama terdapat pada perlakuan perendaman benih kentang selama 60 menit $\left(\mathrm{S}_{4}\right)$ dengan waktu 61 HST yang tidak berbeda nyata dengan perakuan perendaman selama 50 menit $\left(\mathrm{S}_{3}\right)$ dengan waktu 52,0 HST (Tabel 2.). Hal ini menunjukkan semakin lama perlakuan perendaman maka semakin lama masa inkubasi terjadi. Penundaan masa inkubasi tersebut sesuai dengan pendapat Muthahanas et al (2008), yaitu pengaplikasi Streptomyces sp. mampu menghambat masa inkubasi dan menekan intensitas penyakit layu yang terjadi pada tanaman tomat.

Tabel 2. Nilai Rata-Rata Masa Inkubasi (HST) Masing-Masing Perlakuan

\begin{tabular}{lc}
\hline \multicolumn{1}{c}{ Perlakuan } & Masa Inkubasi (HST) ${ }^{*}$ ) \\
\hline $\mathrm{S}_{0}$ (tanpa perlakuan) & $33,0 \mathrm{a}$ \\
$\mathrm{S}_{1}$ (perendaman selama 30 menit) & $40,0 \mathrm{ab}$ \\
$\mathrm{S}_{2}$ (perendaman selama 40 menit) & $45,0 \mathrm{bc}$ \\
$\mathrm{S}_{3}$ (perendaman selama 50 menit) & $52,0 \mathrm{~cd}$ \\
$\mathrm{~S}_{4}$ (perendaman selama 60 menit) & $61,0 \mathrm{~d}$ \\
\hline BNJ 5\% & 11,1
\end{tabular}

${ }^{*}$ : Angka-angka yang diikuti oleh huruf yang sama pada kolom yang sama menunjukan tidak berbeda nyata menurut uji BNJ 5\%

Varietas yang memiliki masa inkubasi tercepat yaitu varietas Mikraset 36,9 HST, yang tidak berbeda nyata dengan varietas Atlantik 49,0 HST namun berbeda nyata pada varietas Mikraset. Varietas Blis menunjukan masa inkubasi terlama yaitu 53,0 HST (Tabel 3.). Hal tersebut menunjukan bahwa varietas Mikraset merupakan varietas 
dengan masa inkubasi tercepat sedangkan varietas Blis menunjukan masa inkubasi terlama. Diduga pada masing-masing varietas memiliki perbedaan ketahanan terhadap serangan penyakit, sehingga masa inkubasi yang terjadi pada masing-masing tanaman ataupun varietas berbeda.

Tabel 3. Nilai Rata-Rata Masa Inkubasi (HST) Masing-Masing Varietas

\begin{tabular}{cc}
\hline Varietas & Masa Inkubasi (HST) \\
\hline $\mathrm{P}_{1}$ (Mikraset) & $36,9 \mathrm{~b}$ \\
$\mathrm{P}_{2}$ (Atlantik) & $49,0 \mathrm{ab}$ \\
$\mathrm{P}_{3}$ (Blis) & $53,0 \mathrm{a}$ \\
\hline BNJ 5\% & 16,6 \\
\hline
\end{tabular}

Keterangan: Angka-angka yang diikuti huruf yang sama pada kolom yang sama menunjukan tidak berbeda nyata menurut BNJ 5\%

Berdasarkan uji keragaman terdapat interaksi antara varietas dengan perlakuan perendaman Dari hasil uji lanjut hasil menunjukan interaksi masa inkubasi tercepat pada varietas Mikraset tanpa perlakuan $\left(\mathrm{P}_{1} \mathrm{~S}_{0}\right)$ yaitu 23,3 HST (Tabel 4.4.), yang tidak berbeda nyata dengan varietas Mikraset dengan perlakuan perendaman 30 menit $\left(\mathrm{P}_{1} \mathrm{~S}_{1}\right)$ yaitu 28,0 HST, varietas Mikraset dengan perlakuan perendaman 40 menit $\left(\mathrm{P}_{1} \mathrm{~S}_{2}\right)$ yaitu 32,7 dan varietas Mikraset dengan perlakuan perendaman 50 menit $\left(\mathrm{P}_{1} \mathrm{~S}_{3}\right)$ yaitu 32,7. Berdasarkan hal tersebut diduga varietas Mikraset lebih rentan dari varietas Atlantik dan varietas Blis terhadap infeksi dari patogen penyebab penyakit, ditambah lagi dengan patogen yang bersifat virulen dengan kondisi yang limgkungan yang mendukung menjadikan proses infeksi dari patogen lebih tinggi. Hal tersebut sesuai dengan konsep segitiga penyakit yang dijelaskan oleh Semangun (2001), penyakit akan terjadai pada suatu waktu apabila terdapat tumbuhan yang rentan, patogen yang virulen dan lingkungan yang sesuai.

Berdasarkan hal tersebut diduga varietas Mikraset lebih rentan dari varietas Atlantik dan varietas Blis terhadap serangan patogen penyebab penyakit, dan semakin lama waktu perendaman benih kentang menunjukan penundaan terhadap masa inkubasi. Interaksi tertinggi masa inkubasi terlama terdapat pada varietas Blis dengan perlakuan lama peredaman selama 60 menit $\left(\mathrm{P}_{3} \mathrm{~S}_{4}\right)$. Diduga karenakan terjadi interaksi terbaik antara benih kentang varietas Blis dengan perlakuan perendaman selama 60 menit dengan agen biopestisida Streptomyces sp. Hal tersebut sesuai dengan Hidayat (2014), dimana varietas Blis merupakan varietas yang tahan terhadap serangan OPT dan diduga terdapat interaksi antara perlakuan biopestisida Streptomyces sp. isolat BSi yang memberikan kemampuan penundaan masa inkubasi tanaman. Sesuai dengan Muthahanas et al (2010), dimana isolat BSi tersebut dapat menghambat masa inkubasi sampai 53 hari, dan menurunkan intensitas penyakit. 
Tabel 4. Interaksi Antara Varietas Dengan Perlakuan Lama Perendaman Terhadap Masa Inkubasi

\begin{tabular}{|c|c|}
\hline Varietas*Perendaman & Masa Inkubasi (HST) ${ }^{*}$ \\
\hline $\mathrm{P}_{1} \mathrm{~S}_{0}$ & 23,3 hi \\
\hline $\mathrm{P}_{1} \mathrm{~S}_{1}$ & 28,0 hi \\
\hline $\mathrm{P}_{1} \mathrm{~S}_{2}$ & 32,7 ghi \\
\hline $\mathrm{P}_{1} \mathrm{~S}_{3}$ & 32,7 ghi \\
\hline $\mathrm{P}_{1} \mathrm{~S}_{4}$ & 56,0 abcd \\
\hline $\mathrm{P}_{2} \mathrm{~S}_{0}$ & 37,3 fgh \\
\hline $\mathrm{P}_{2} \mathrm{~S}_{1}$ & 49,0 cdef \\
\hline $\mathrm{P}_{2} \mathrm{~S}_{2}$ & 46,7 defg \\
\hline $\mathrm{P}_{2} \mathrm{~S}_{3}$ & 51,3 bcde \\
\hline $\mathrm{P}_{2} \mathrm{~S}_{4}$ & $63,0 \quad a b$ \\
\hline $\mathrm{P}_{3} \mathrm{~S}_{0}$ & 39,7 efgh \\
\hline $\mathrm{P}_{3} \mathrm{~S}_{1}$ & 42,0 efg \\
\hline $\mathrm{P}_{3} \mathrm{~S}_{2}$ & 56,0 abcd \\
\hline $\mathrm{P}_{3} \mathrm{~S}_{3}$ & 60,7 abc \\
\hline $\mathrm{P}_{3} \mathrm{~S}_{4}$ & 65,3 a \\
\hline BNJ 5\% & 13,7 \\
\hline
\end{tabular}
sedangkan $\mathrm{S} 0=$ tanpa perlakuan, $\mathrm{S} 1=$ perendaman benih kentang selama 30 menit, $\mathrm{S} 2=$ perendaman benih kentang selama 40 menit, $\mathrm{S} 3=$ perendaman benih kentang selama50 menit, S4= perendaman benih kentang selama 60 menit. ${ }^{*}$ : Angka-angka yang diikuti oleh huruf yang sama pada kolom yang sama menunjukan tidak berbeda nyata menurut uji BNJ 5\%

\section{Identifikasi Penyebab Penyakit}

Setelah dilakukan identifikasi berdasarkan Illustrated General of Imperfect Fungi (Barnet \& Hunter, 1978) dan Practical Guide to Detection and Identification of Phytopthora (Drenth \& Sendall, 2001), diperoleh dua jenis patogen yang menginfeksi tanaman kentang yaitu $P$. infestans dan Fusarium sp..

\section{a. Phytopthora infestans.}

Tanaman yang terinfeksi jamur $P$. infestans memiliki gejala awal yang terdapat pada daun yaitu bercak berwarna coklat kegelapan. Proses infeksi awal patogen ini dimulai dari pinggir daun kemudian menyebabkan tanaman layu sehingga dapat mematikan tanaman kentang yang terinfeksi. Gambar tanaman yang memiliki gejala terinfeksi $P$. infestans dapat dilihat pada (Gambar 1). Hal tersebut sesuai dengan Semangun (2007) yang menyatakan tanaman yang terinfeksi $P$. infestans memiliki gejala awal terdapat bercak-bercak nekrotis pada tepi daun dan ujungnya. Pengamatan secara mikroskopis memperlihatkan konidiofor yang tidak bersekat serta terdapat konidia tunggal pada ujung konidiofor. Konidia memiliki bentuk seperti buah lemon dengan bentuk bulat dan sedikit runcing pada bagian ujungnya. Pengamatan makroskopis dan mikroskopis dapat dilihat pada (Gambar 1). Hal tersebut sesuai dengan pernyataan Semangun (2007), bahwa P.infestans memiliki miselium interseluler, tidak bersekat terdapat banyak haustorium. Konidiofor yang berasal dari mulut kulit, terdapat bengkakan yang khas. Terdapat konidium yang berbentuk seperti buah peer. 

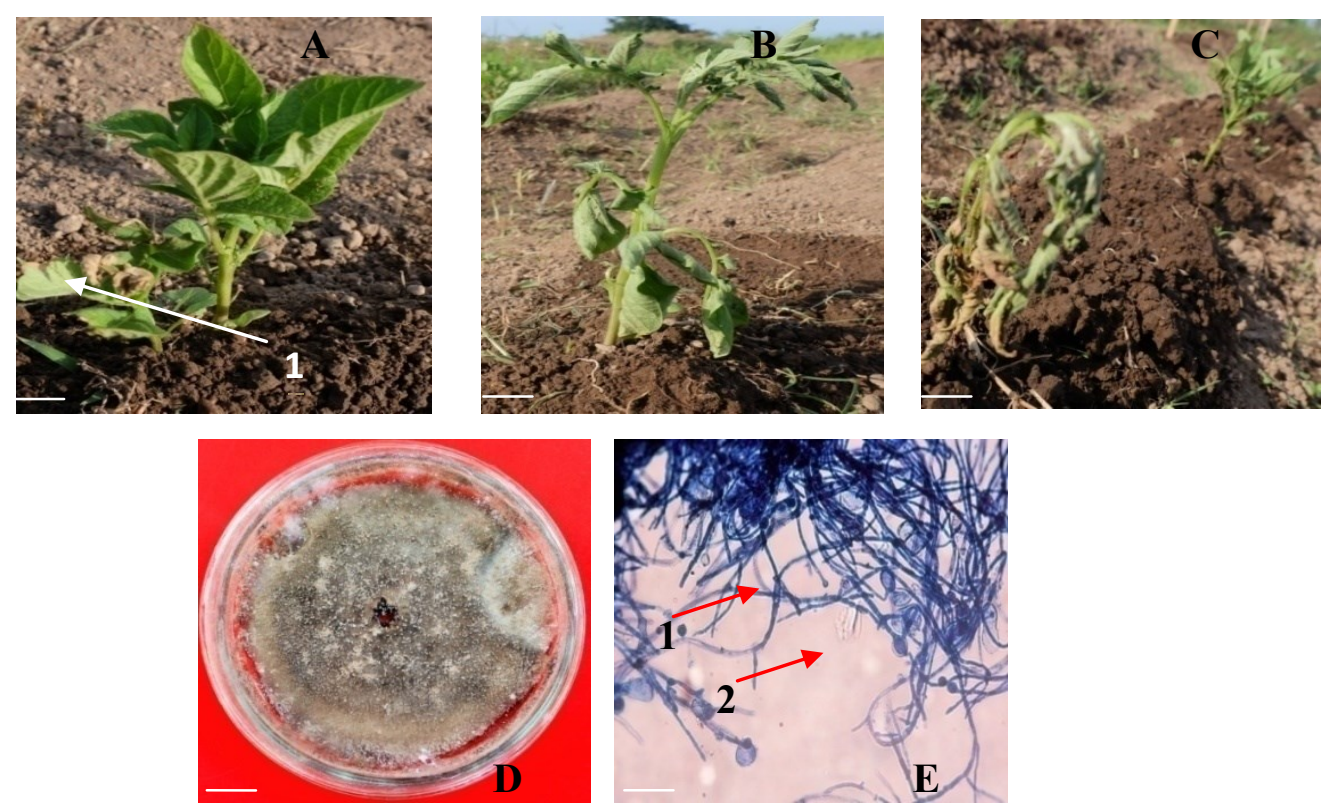

Gambar 1. Gejala Penyakit Yang Disebabkan Oleh Jamur P. Infestans Pada Tananam Kentang (A) Gejala Awal Yang Berupa Bercak (skala__10 cm), (B) Bercak Yang Terdapat Pada Daun (skala $\_10 \mathrm{~cm}$ ), (1) Gejala Layu, (C) Tanaman Mati Daun (skala $10 \mathrm{~cm}$ ), (D) Bentuk Jamur Secara Makroskopis (skala_3 cm),(E) Bentuk Jamur Secara Mikroskopis Pada Perbesaran 400x (1) Konidiofor (2) Konidia.

Tabel 5. Nilai Rata-Rata Insiden Penyakit Yang Disebabkan Oleh Jamur Patogen P.Infestans Pada Masing-Masing Perlakuan

\begin{tabular}{cc}
\hline Perlakuan & $\begin{array}{c}\text { Insiden penyakit } \\
\text { (P. infestans) }(\%)\end{array}$ \\
\hline $\mathrm{S}_{0}$ (tanpa perlakuan) & $66,9 \mathrm{a}$ \\
$\mathrm{S}_{1}$ (perendaman selama 30 menit) & $52,9 \mathrm{ab}$ \\
$\mathrm{S}_{2}$ (perendaman selama 40 menit) & $46,9 \mathrm{ab}$ \\
$\mathrm{S}_{3}$ (perendaman selama 50 menit) & $37,1 \mathrm{~b}$ \\
$\mathrm{~S}_{4}$ (perendaman selama 60 menit) & $34,0 \mathrm{~b}$ \\
\hline BNJ 5\% & 23,0 \\
\hline
\end{tabular}

Keterangan: Angka-angka yang diikuti huruf yang sama pada kolom yang sama menunjukan tidak berbeda nyata menurut BNJ 5\%

Insiden penyakit yang disebabkan oleh patogen $P$. infestans yang ditemukan pada perlakuan $\mathrm{S}_{0}$ memiliki presentase tertinggi yaitu $66,9 \%$ tidak berbeda nyata dengan $\mathrm{S}_{1}$ yaitu $52,9 \%$ dan $46,9 \%$ untuk $\mathrm{S}_{2}$, namun berbeda nyata dengan $\mathrm{S}_{3}$ sebesar $37,1 \%$ dan S4 yaitu 34,0\% (Tabel 5.). Hal ini diduga karena semakin lama waktu perendaman maka semakin banyak agen hayati Streptomyces isolat BSi yang memberikan system pertahanan terhadap jamur penyebab penyakit. Terlihat pada (Tabel 6.) tersebut presentase insiden yang paling tinggi disebabkan oleh jamur P. infestan. Presentase insiden penyakit tertinggi terjadi pada varietas Mikraset yaitu sebesar 55,67\%, yang tidak berbeda nyata dengan varietas Atlantik yaitu sebesar 47,00\% namun berbeda nyata dengan varietas Blis yaitu sebesar $40,00 \%$. Presentase insiden penyakit Varietas Atlantik sebesar $47 \%$ yang tidak berbeda nyata dengan varietas Mikraset dan Blis. Hal 
tersebut menunjukan varietas Mikraset memiliki insiden penyakit tertinggi yang disebabkan oleh jamur $P$. infestans. Varietas yang menunjukan insiden penyakit lebih rendah terdapat varietas Blis.

Tabel 6. Nilai Rata-Rata Insiden Penyakit P. Infestans Masing-Masing Varietas

\begin{tabular}{cc}
\hline Varietas & $\begin{array}{c}\text { Insiden penyakit } \\
(P . \text { infestans) }(\%)\end{array}$ \\
\hline $\mathrm{P}_{1}$ (Mikraset) & $55,7 \mathrm{a}$ \\
$\mathrm{P}_{2}$ (Atlantik) & $47,0 \mathrm{ab}$ \\
$\mathrm{P}_{3}$ (Blis) & $40,0 \mathrm{~b}$ \\
\hline BNJ 5\% & 11,5 \\
\hline
\end{tabular}

Keterangan: Angka-angka yang diikuti huruf yang sama pada kolom yang sama menunjukan tidak berbeda nyata menurut $\mathrm{BNJ} 5 \%$

Kerentanan yang dimiliki oleh varietas Mikraset terhadap jamur penyebab penyakit hawar daun yaitu $P$. infestan diduga menjadi salah satu penyebabnya. Hal tersebut sesuai dengan Hidayat (2014), dimana genotipe yang rentan terserang oleh penyakit hawar daun ( $P$. infestans) yaitu varietas Atlantik, Mikraset dan Bukit Tinggi. Di dataran medium umumnya memiliki suhu yang lebih tinggi dibandingkan di dataran tinggi, untuk beberapa jenis patogen menjadikan lingkungan optimum bagi perkembangannya. Selain itu penanaman yang dilakukan diluar musim tanaman yaitu pada musim penghujan (Desember-Maret) memberikan keadaan yang sesuai bagi perkembangan patogen penyebab penyakit $P$. infestans. Semangun (2007), menyatakan epidemik penyakit hawar daun ini dapat terjadi pada suhu $16-24^{\circ} \mathrm{C}$, di dataran tinggi jawa terjadi perkembangan penyakit pada musim penghujan yang dingin, antara bulan Desember-Februari.

\section{b. Fusarium sp.}

Pada tanaman kentang yang terinfeksi Fusarium sp. memiliki gejala layu. Gejala dimulai dari bagian akar tanaman kemudianmenyebar menuju bagian atas. Gejala layu pada bagian daun yamg tua menjadi kuning, pada bagian batang tanaman berwarna coklat hingga mengering. Hal tersebut sesuai dengan pernyataan Semangun (2007), dimana gejala awal yang terjadi apabila tanaman terinfeksi Fusarium sp. yaitu terutama bagian daun bawah yang menguning. Selain itu tanaman menjadai layu secara keseluruhan akibat terserang pada bagian batang bawah yang menjadai coklat hal tersebut bersumber dari akar yang yang terserang oleh Fusarium sp. Hal tersebut dapat dlihat pada (Gambar 2.).

Pada pengamatan makroskopis dan mikroskopis didapatkan hasil seperti yang terlihat pada (Gambar 2). Pengamatan yang dilakukan secara mikroskopis terlihat konidium yang memiliki bentuk seperti bulan sabit silinder. Ditemukan dua jenis yang ditemukan yaitu makrokonidia yang memiliki 3-4 sekat dan mikrokonidia yang memiliki ukuran yang lebih kecil serta tidak memiliki sekat. Hal tersebut sesuai dengan pernyataan Semangun (2007), dimana spesies Fusarium sp. mempunyai konidium yang berbentuk seperti bulan sabit, yang pada umumnya memiliki sekat berjumlah 3 . 

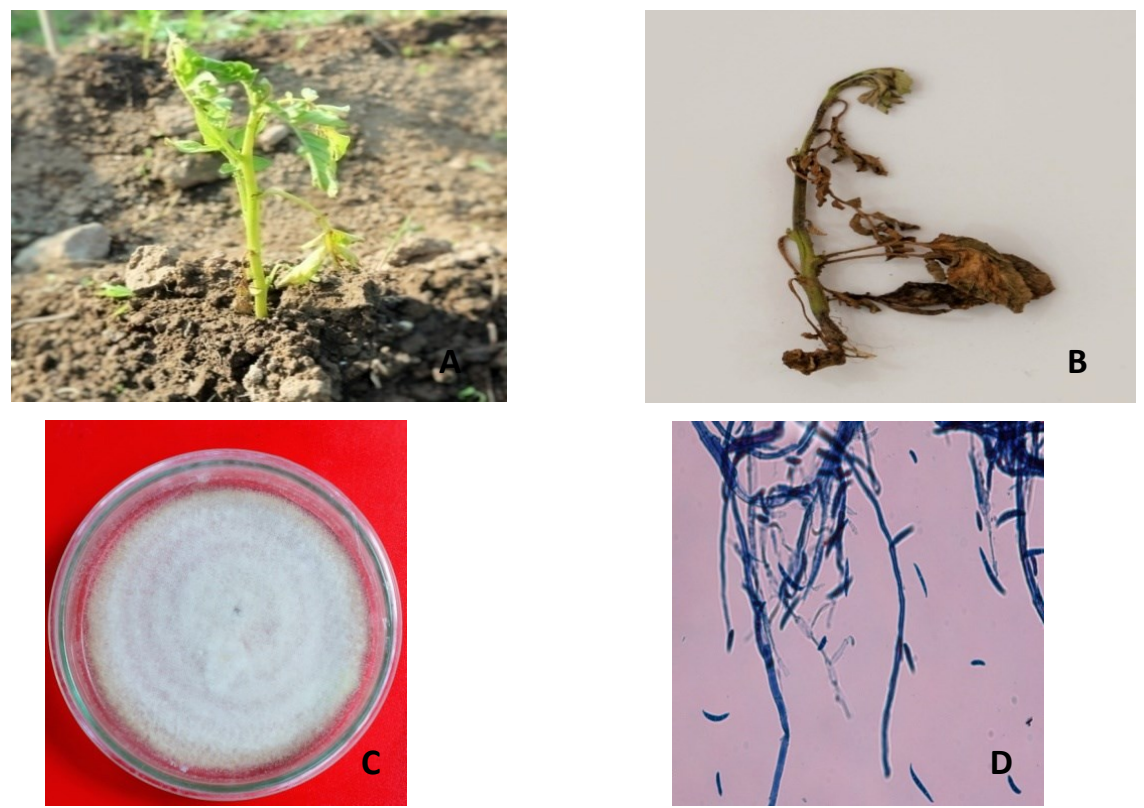

Gambar 2. (A) Gejala layu Fusarium pada pada tanaman kenntang (B) Gejala layu kemudian menjadi kering (C) Hasil pengamatan makroskopis jamur Fusarium sp., (D) Hasil pengamatan mikroskopis pada perbesaran 400x

Insiden penyakit yang disebabkan oleh patogen jamur Fusarium sp. pada perlakuan $\mathrm{S}_{4}$ atau perendaman dengan waktu 60 menit tidak ditemukan. Hal tersebut berbeda nyata pada perlakuan $\mathrm{S}_{0}$ yaitu sebesar $26,2 \%$ yang tidak berbeda nyata dengan perlakuan pada $\mathrm{S}_{1}$ yaitu $194 \%$ dan $\mathrm{S}_{2}$ yaitu sebesar 13,8\% namun berbeda nyata dengan perlakuan $\mathrm{S}_{3}$ yaitu sebesar $4,2 \%$ (Tabel 7.). Perlakuan $\mathrm{S}_{4}$ atau perendaman dengan waktu 60 menit menunjukan waktu terbaik perendaman dengan menggunakan Biopestisida Streptomyces sp isolat BSi. Hal tersebut dikarenakan tidak ditemukannya insiden penyakit yang disebabkan oleh Fusarium Sp..

Tabel 7. Nilai rata-rata Insiden Penyakit Yang Disebabkan Oleh Jamur Patogen Fusarium sp. Pada Masing-Masing Perlakuan

\begin{tabular}{lc}
\hline \multicolumn{1}{c}{ Perlakuan } & Insiden penyakit (\%) $\left.^{*}\right)$ \\
\hline $\mathrm{S}_{0}$ (tanpa perlakuan) & $26,2 \mathrm{a}$ \\
$\mathrm{S}_{1}$ (perendaman selama 30 menit) & $19,4 \mathrm{ab}$ \\
$\mathrm{S}_{2}$ (perendaman selama 40 menit) & $13,8 \mathrm{ab}$ \\
$\mathrm{S}_{3}$ (perendaman selama 50 menit) & $4,2 \mathrm{~b}$ \\
$\mathrm{~S}_{4}$ (perendaman selama 60 menit) & $0,0 \mathrm{~b}$ \\
\hline BNJ 5\% & 19,5 \\
\hline
\end{tabular}

*): Angka-angka yang diikuti oleh huruf yang sama pada kolom yang sama menunjukan tidak berbeda nyata menurut uji BNJ 5\%

Dimana pada tanaman kentang dapat menyebabkan terjadinya penyakit layu. Diduga hal tersebut pengaruh dari perlakuan perendaman biopestisida Streptomyces sp. isolat BSi yang mampu menekan patogen penyebab penyakit yang disebabkan oleh Fusarium sp. Perlakuan perendaman yang dilakukan diduga berkaitan dengan anatomi dari benih kentang tersebut. Sesuai dengan pernyataan Nurainal (2012), dimana kentang tergolong dalam tanaman dikotil sehingga pada organ tanaman muda memiliki jaringan pelindung berupa epidermis. Akibat pertumbuhan sekunder pada organ dikotil yang 
dewasa fungsi perlindungan digantikan oleh felem yang dihasilkan oleh kambium gabus. Sehingga diduga pada saat perlakuan perendaman jaringan gabus mempermudah terjadinya proses imbibisi dari larutan biopestisida Streptomyces sp. isolat BSi tersebut. Mudahnya proses imbibisi yang terjadi diduga menjadi pendukung proses proteksi dilakukan oleh Streptomyces sp. dalam memberikan pertahanan bagi BENIH kentang dari serangan Fusarium sp.

Insiden penyakit yang disebabkan oleh jamur Fusarium sp. dengan jumlah presentase tertinggi (Tabel 8.) ditemukan pada varietas Mikraset yaitu sebesar 15,4\% yang tidak berbeda nyata pada varietas Atlantik sebesar 12,0\% namun berbeda nyata dengan varietas Blis yaitu sebesar 11,0\%. Berdasarkan hal tersebut varietas Mikraset memiliki insiden penyakit yang disebabkan oleh jamur Fusarium Sp. tertinggi dan insiden penyakit terendah terdapat pada varietas Blis. Hal ini menunjukan presentase insiden penyakit yang disebabkan oleh jamur Fusarium sp. baik pada perlakuan maupun varietas tidak setinggi presentase insiden penyakit yang disebabkan oleh $P$. infestans, diduga hal tersebut menunjukan kemampuan dari agen hayati Streptomyces isolat BSi yang dapat menekan penyakit yang disebabkan oleh Fusarium sp. Penelitian Kawuri (2012), menyatakan kemampuan daya hambat Streptomyces thermocarboxydus mampu menghambat Fusarium sp. sebesar 93,00 \%, dengan mekanisme kerja melalui perusakan pada dinding sel makrokonidia, klamidiospora dan mikrokonidia yang terlihat melalui pengamatan TEM (Transmision Electron Microscop) dan SEM (Scanning Electron Microscop). Tabel 8. Nilai Rata-Rata Insiden Penyakit Yang Disebabkan Oleh Jamur Patogen Fusarium sp. Pada Masing-Masing Varietas

\begin{tabular}{cc}
\hline Varietas & Insiden penyakit (\%) ${ }^{*}$ \\
\hline $\mathrm{P}_{1}$ (Mikraset) & $15,4 \mathrm{a}$ \\
$\mathrm{P}_{2}$ (Atlantik) & $12,0 \mathrm{ab}$ \\
$\mathrm{P}_{3}$ (Blis) & $11,0 \mathrm{~b}$ \\
\hline BNJ 5\% & 3,6 \\
\hline
\end{tabular}

${ }^{*}$ : Angka-angka yang diikuti oleh huruf yang sama pada kolom yang sama menunjukan tidak berbeda nyata menurut uji BNJ 5\%

Lama perendaman biopestisida yang berbeda menghasilkan jumlah umbi per petak yang berbeda menghasilkan hasil yang berbeda. Perlakuan $\mathrm{S}_{0}$ sebanyak 13,0 umbi/petak yang tidak berbeda nyata dengan $\mathrm{S}_{1}$ yaitu 20,0 umbi/petak dan $\mathrm{S}_{2}$ sebanyak 22,0 umbi/petak tetapi erbeda nyata dengan perlakuan $\mathrm{S}_{3}$ yaitu sebanyak 28,0 umbi/petak. Perlakuan $\mathrm{S}_{4}$ yang berbeda nyata dengan perlakuan lainnya yaitu sebanyak 34,0 umbi/petak. Pada parameter jumlah umbi per tanaman didapatkan rerata perlakuan $\mathrm{S}_{0}$ (2,5 umbi/petak) yang berbeda nyata dengan $\mathrm{S}_{1}$ (3,3 umbi/petak), $\mathrm{S}_{2}$ (39 umbi/petak), $\mathrm{S}_{3}$ (4,6 umbi/petak) dan $\mathrm{S}_{4}$ yaitu (5,7 umbi/petak).

Hasil yang tertinggi rerata berat pe rumbi diperoleh pada perlakuan $\mathrm{S}_{4}$ seberat $38,2 \mathrm{~g} / \mathrm{umbi}$ yang tidak berbeda nyata dengan perlakuan $\mathrm{S}_{3}$ yaitu $33,4 \mathrm{~g} / \mathrm{umbi}$ dan berbeda nyata dengan perlakuan $\mathrm{S}_{2}$ yaitu seberat $24,5 \mathrm{~g} / \mathrm{umbi}$ tanaman, $\mathrm{S}_{1}$ yaitu seberat 22,8 g/umbi tanaman dan $\mathrm{S}_{0}$ seberat 20.9 g/umbi tanaman. Pada perlakuan $\mathrm{S}_{4}$ didapatkan rerata berat umbi per petak tertinggi dengan hasil yaitu $16.957,1 \mathrm{~g} /$ petak dimana perlakuan $\mathrm{S}_{4}$ berbeda nyata dengan seluruh perlakuan. Diikuti dengan perlakuan $\mathrm{S}_{3}$ menghasilkan rerata berat umbi per petak yaitu seberat 15.004,8 g/petak, $\mathrm{S}_{2}$ menghasilkan rerata berat $11.135,0 \mathrm{~g} /$ petak, $\mathrm{S}_{1}$ dengan rerata berat $8.865,8 \mathrm{~g} /$ petak $\mathrm{S}_{0}$ menghasilkan yang terendah terendah yaitu dengan rerata $6.794,8 \mathrm{~g} /$ petak. 
Tabel 9. Nilai Rata-Rata Produksi Jumlah Umbi Per Petak, Jumlah Umbi Per Tanaman, Berat Satu Umbi, Berat Umbi Per Petak Pada Perlakuan Lama Perendaman

\begin{tabular}{lcccc}
\hline Perlakuan & $\begin{array}{c}\text { Jumlah } \\
\text { Umbi/Petak }\end{array}$ & $\begin{array}{c}\text { Jumlah } \\
\text { Umbi/Tanaman }\end{array}$ & $\begin{array}{c}\text { Berat Satu } \\
\text { Umbi (g/umbi) }\end{array}$ & $\begin{array}{c}\text { Berat } \\
\text { Umbi/Petak } \\
\left(\mathrm{g} / \text { petak) }{ }^{*}\right.\end{array}$ \\
\hline $\mathrm{S}_{0}$ (Tanpa) & $13,0 \mathrm{c}$ & $2,5 \mathrm{~d}$ & $20,9 \mathrm{c}$ & $6.794,8 \mathrm{e}$ \\
$\mathrm{S}_{1}$ (30 menit) & $20,0 \mathrm{c}$ & $3,3 \mathrm{c}$ & $22,7 \mathrm{c}$ & $8.865,8 \mathrm{~d}$ \\
$\mathrm{~S}_{2}$ (40 menit) & $22,0 \mathrm{c}$ & $3,8 \mathrm{c}$ & $24,5 \mathrm{bc}$ & $11.135,1 \mathrm{c}$ \\
$\mathrm{S}_{3}$ (50 menit) & $28,0 \mathrm{~b}$ & $4,6 \mathrm{~b}$ & $33,4 \mathrm{ab}$ & $15.004,8 \mathrm{~b}$ \\
$\mathrm{~S}_{4}$ (60 menit) & $34,0 \mathrm{a}$ & $5,7 \mathrm{a}$ & $38,2 \mathrm{a}$ & $16.957,1 \mathrm{a}$ \\
\hline BNJ 5\% & 8,5 & 0,7 & 9,3 & 143,4 \\
\hline
\end{tabular}

${ }^{*}$ : Angka-angka yang diikuti oleh huruf yang sama pada kolom yang sama menunjukan tidak berbeda nyata menurut uji BNJ 5\%

Dari hasil tersebut diketahui semakin lama waktu perendaman dengan waktu 60 menit yaitu pada perlakuan $\mathrm{S}_{4}$ didapatkan hasil tertinggi baik untuk jumlah umbi perpetak, jumlah umbi pertanaman, berat perumbi dan berat umbi perpetak yang diikuti dibawahnya secara berturut-turut pada perlakuan $S_{3}, S_{2}, S_{1}$ dan yang terendah pada $S_{0}$ yaitu tanpa perlakuan. Diduga perlakuan dengan menggunakan agen hayati Streptomyces sp. isolat BSi dapat memacu produksi pada tanaman kentang. Menurut Lehr et al. (2008), terdapat senyawa yang dapat memicu pertumbuhan tanaman seperti auksin, giberelin dan sitokinin yang dihasilkan oleh Streptomyces sp.. Selain menghasilkan senyawa antibiotik, Streptomyces sp. memiliki kemampuan dalam memproduksi auksin indole-3-acetid acid (IAA) yang berfungsi dalam menstimulasi pertumbuhan tanaman (Tuomi, et al.. 1994 dalam Aryantha et al., 2004).

Pada varietas (Tabel 10.) rerata jumlah umbi perpetak di dapatkan hasil yaitu untuk varietas Mikraset sebanyak 13 umbi yang tidak berbeda nyata dengan varietas Atlantik sebanyak 24,0 umbi. Pada varietas ditemukan jumlah umbi pertanaman paling banyak pada varietas Blis yaitu sebanyak 5,7 umbi yang tidak berbeda nyata pada varietas Atlantik yaitu sebanyak 3,7 umbi namun berbeda nyata pada varietas Mikraset yaitu sebanyak 2,5 umbi. Varietas dengan berat umbi per petak tertinggi terdapat pada varietas Blis dengan rerata berat per petak sebesar 25.021,5 gr yang berbeda nyata dengan kedua varietas lain yaitu Atlantik rata-rata seberat 18.999,4 gr dan Mikraset dengan berat $14.736,7$ gr. Varietas dengan berat satuan umbi tertinggi yaitu pada varietas Mikraset seberat 35,2 gr tanaman yang tidak berbeda nyata dengan varietas Atlantik yaitu seberat 29,7 gr/ tanaman dan berbeda nyata pada varietas Blis yaitu seberat 20.5 gr tanaman.

Tabel 10. Nilai Rata-Rata Produksi Jumlah Umbi Per Petak, Jumlah Umbi Per Tanaman, Berat Satu Umbi, Berat Umbi Per Petak Pada Masing-Masing Varietas

\begin{tabular}{lcccc}
\hline \multicolumn{1}{c}{ Varietas } & $\begin{array}{c}\text { Jumlah } \\
\text { Umbi/Petak }\end{array}$ & $\begin{array}{c}\text { Jumlah } \\
\text { Umbi/Tanaman }\end{array}$ & $\begin{array}{c}\text { Berat Satu } \\
\text { Umbi }(\mathrm{g})\end{array}$ & $\begin{array}{c}\text { Berat Umbi } \\
\left(\mathrm{g} / \text { petak) }{ }^{*}\right.\end{array}$ \\
\hline $\mathrm{P}_{1}$ (Mikraset) & $13,0 \mathrm{~b}$ & $2,5 \mathrm{~b}$ & $35,2 \mathrm{a}$ & $1.4736,7 \mathrm{~b}$ \\
$\mathrm{P}_{2}$ (Atlantik) & $24,0 \mathrm{ab}$ & $3,7 \mathrm{ab}$ & $29,7 \mathrm{ab}$ & $1.8999,4 \mathrm{~b}$ \\
$\mathrm{P}_{3}$ (Blis) & $34,0 \mathrm{a}$ & $5,7 \mathrm{a}$ & $20,5 \mathrm{~b}$ & $2.5021,5 \mathrm{a}$ \\
\hline \multicolumn{1}{c}{ BNJ 5\% } & 17,7 & 3,2 & 14,2 & 598,9 \\
\hline
\end{tabular}

${ }^{*}$ : Angka-angka yang diikuti oleh huruf yang sama pada kolom yang sama menunjukan tidak berbeda nyata menurut uji BNJ 5\% 
Dari data tersebut yang paling rendah nilai keempat parameter produksi tersebut yaitu varietas Mikraset kemudian Atlantik dan yang paling tinggi adalah varietas Blis. Rendahnya produksi pada varietas Mikraset diduga terpengaruh oleh kerentanan yang dimiliki oleh varietas, terutama terhadap $P$, infestans sehingga menurunkan hasil dan produksi dari tanaman kentang. Hal tersebut sesuai pernyataan Hidayat (2014), dimana varietas yang rentan terhadap penyakit hawar daun $(P$, infestans) diantaranya varietas Mikraset, Atlantik, dan Bukit Tinggi. Varietas yang memiliki produksi tertinggi yaitu Blis diduga karena varietas tersebut lebih tahan terhadap serangan penyakit dan terdapat pengaruh Streptomyces sp. menunjang pertumbuhan tanaman ketang sehingga memiliki produksi yang baik. Haas \& Devago dalam Hidayat (2017), mengemukakan bahwa Streptomyces sp. merupakan salah satu mikroorganisme yang tergolong dalam rhizobacteria yang mampu mengkolonisasi rizosfer tanaman dan bersimbiosis dengan perakaran tanaman. Bakteri yang berasosiasi dengan akar tanaman biasa disebut Plant Growth-Promoting Rhizobacteria (PGPR). Berdasarkan analisis keragaman untuk jumlah umbi per tanaman, berat umbi per petak, dan berat satuan umbi didapatkan hasil yang signifikan terbukti dengan diperoleh nilai p 5\% $(0,05)$ pada varietas dan perlakuan. Interaksi tertinggi berat umbi per petak terdapat pada varietas Blis dengan perendaman selama 60 menit $\left(\mathrm{P}_{3} \mathrm{~S}_{4}\right)$ dengan hasil yaitu 7,3 dan interaksi terendah jumlah umbi pertanaman terdapat pada $\mathrm{P}_{1} \mathrm{~S}_{0}$ yang tidak berbeda nyata dengan $\mathrm{P}_{1} \mathrm{~S}_{1}, \mathrm{P}_{1} \mathrm{~S}_{2}$ dan $\mathrm{P}_{1} \mathrm{~S}_{4}$ (Tabel 4.11.). Hasil interaksi antara varietas dengan perlakuan pada berat umbi per petak diperoleh hasil tertinggi pada varietas Blis dengan perlakuan perendaman 50 menit $\left(\mathrm{P}_{3} \mathrm{~S}_{3}\right)$ yaitu seberat $2.087,2 \mathrm{~g} /$ petak. Hal tersebut tidak berbeda nyata dengan varietas Atlantik pada lama perendaman 60 menit $\left(\mathrm{P}_{2} \mathrm{~S}_{4}\right)$ yaitu seberat 2.104,2 g/petak, varietas Blis dengan lama perendaman 60 menit $\left(\mathrm{P}_{3} \mathrm{~S}_{4}\right)$ seberat $1.623,7 \mathrm{~g} /$ petak, varietas Blis dengan lama perendaman 40 menit $\left(\mathrm{P}_{3} \mathrm{~S}_{2}\right) 1.623,7 \mathrm{~g} /$ petak, varietas Mikraset dengan lama perendaman 60 menit $\left(\mathrm{P}_{1} \mathrm{~S}_{4}\right)$ seberat $1.653,7 \mathrm{~g} /$ petak dan varietas Atlantik dengan lama perendaman 50 menit $\left(\mathrm{P}_{2} \mathrm{~S}_{3}\right)$ yaitu seberat $1.590,8 \mathrm{~g} /$ petak.

Tabel 11. Interaksi Antara Varietas Dengan Perendaman Pada Jumlah Umbi Per Tanaman, Berat Umbi Per Petak Dan Berat Umbi Per Tanaman

\begin{tabular}{|c|c|c|c|}
\hline Varietas*Perendaman & $\begin{array}{c}\text { Jumlah } \\
\text { Umbi/Tanaman }\end{array}$ & $\begin{array}{c}\text { Berat Umbi/Petak } \\
\text { (g/petak) }\end{array}$ & $\begin{array}{l}\text { Berat } \\
\text { Satuan } \\
\left.\text { Umbi }(g)^{*}\right)\end{array}$ \\
\hline $\mathrm{P}_{1} \mathrm{~S}_{0}$ & $1,4 \mathrm{I}$ & $552,6 \mathrm{f}$ & 24,5 def \\
\hline $\mathrm{P}_{1} \mathrm{~S}_{1}$ & $2,0 \quad \mathrm{Hi}$ & 957,1 cdef & 28,4 de \\
\hline $\mathrm{P}_{1} \mathrm{~S}_{2}$ & $2,0 \quad \mathrm{Hi}$ & 970,8 cdef & $28,8 \mathrm{~d}$ \\
\hline $\mathrm{P}_{1} \mathrm{~S}_{3}$ & $2,0 \quad \mathrm{Hi}$ & 1323,6 bcd & 39,9 bc \\
\hline $\mathrm{P}_{1} \mathrm{~S}_{4}$ & $2,8 \mathrm{Gh}$ & $1653,7 \quad a b$ & 54,3 a \\
\hline $\mathrm{P}_{2} \mathrm{~S}_{0}$ & $2,6 \mathrm{Gh}$ & 738,6 ef & $22,1 \quad \mathrm{fg}$ \\
\hline $\mathrm{P}_{2} \mathrm{~S}_{1}$ & $3,0 \quad \mathrm{G}$ & 782,3 def & 20,9 fgh \\
\hline $\mathrm{P}_{2} \mathrm{~S}_{2}$ & $3,3 \quad \mathrm{Fg}$ & 1117,2 bcde & 23,2 efg \\
\hline $\mathrm{P}_{2} \mathrm{~S}_{3}$ & $3,8 \quad \mathrm{Ef}$ & 1590,8 abc & $38,3 \quad \mathrm{c}$ \\
\hline $\mathrm{P}_{2} \mathrm{~S}_{4}$ & $4,3 \quad \mathrm{E}$ & $2104,2 \quad a$ & $43,9 \mathrm{ab}$ \\
\hline $\mathrm{P}_{3} \mathrm{~S}_{0}$ & 4,7 De & 973,7 cdef & $16,1 \mathrm{~h}$ \\
\hline $\mathrm{P}_{3} \mathrm{~S}_{1}$ & $5,3 \mathrm{Cb}$ & 1215,8 bcde & $18,9 \mathrm{gh}$ \\
\hline $\mathrm{P}_{3} \mathrm{~S}_{2}$ & $6,0 \quad \mathrm{Bc}$ & $1623,7 \mathrm{ab}$ & 2,4 fgh \\
\hline $\mathrm{P}_{3} \mathrm{~S}_{3}$ & $6,7 \mathrm{Ab}$ & 2087,2 a & 2,9 fg \\
\hline $\mathrm{P}_{3} \mathrm{~S}_{4}$ & $7,3 \quad \mathrm{~A}$ & $1623,7 \mathrm{ab}$ & 2,9 efg \\
\hline BNJ 5\% & 0,9 & 146,7 & 11,3 \\
\hline
\end{tabular}


Keterangan: $\mathrm{P} 1=$ Varietas Mikraset, $\mathrm{P} 2=$ Varietas Atlantik, $\mathrm{P} 3=$ Varietas Blis, sedangkan $\mathrm{S} 0=$ tanpa perlakuan, $\mathrm{S} 1=$ perendaman benih kentang selama 30 menit, S2= perendaman benih kentang selama 40 menit, S3= perendaman benih kentang selama50 menit, $\mathrm{S} 4=$ perendaman benih kentang selama 60 menit. ${ }^{*}$ : Angka-angka yang diikuti oleh huruf yang sama pada kolom yang sama menunjukan tidak berbeda nyata menurut uji BNJ $5 \%$

Terdapat interaksi antara varietas dengan lama perendaman dalam mempengaruhi hasil tanaman kentang. Pada berat umbi per tanaman, hasil tertinggi diperoleh pada varietas Mikraset dengan lama perendaman 60 menit $\left(\mathrm{P}_{1} \mathrm{~S}_{4}\right)$ seberat 54,3 $\mathrm{g}$ yang tidak berbeda nyata dengan varietas Atlantik dengan lama perendaman 60 menit $\left(\mathrm{P}_{2} \mathrm{~S}_{4}\right)$ seberat 43,9 g. Meskipun demikian pada jumlah umbi per tanaman, berat umbi per petak maupun berat umbi per tanaman terdapat interaksi yang terjadi antara varietas Atlantik dengan perlakuan lama perendaman biopestisida 60 menit dan varietas Blis dengan perlakuan lama perendaman biopestisida 50 menit menghasilkan produksi tertinggi. Perlakuan biopestisida Streptomyches sp. yang diberikan tersebut diduga menjadi salah satu faktor yang dapat memacu pertumbuhan tanaman sehingga tidak hanya memberikan ketahanan terhadap serangan patogen penyebab penyakit tetapi juga menghasilkanmeningkatkan pertumbuhan dan hasil tanaman. Muthahanas \& Listiana (2008), berpendapat bahwa Streptomyces sp. tergolong dalam mikroorganisme rhizobacteria yang memiliki kemampuan dalam mengkolonisasi rizosfer pada tanaman dan membentuk simbiosis dengan perakaran tanaman sehingga dapat meningkatkan produksi. Streptomyces dapat merangsang pertumbuhan tanaman dan memberikan perlindungan terhadap tanaman dari serangan penyakit.

\section{KESIMPULAN DAN SARAN}

\section{Kesimpulan}

1. Streptomyces isolat BSi menunjukan kemampuan terbaik dalam menghambat jamur patogen $S$. rolfsii dan Fusarium sp. yang di uji secara in-vitro.

2. Ditemukan dua jamur patogen yang menginfeksi tanaman kentang antara lain $P$. infestans dan Fusarium sp..

3. Perendaman biopestisida Streptomyces sp. isolat BSi selama 60 menit $\left(\mathrm{S}_{4}\right)$ dan varietas Blis $\left(\mathrm{P}_{3}\right)$ yang paling efektif dalam menunda masa inkubasi, menekan persentase dari infeksi patogen $P$. infestans dan Fusarium sp..

4. Interaksi terbaik untuk menunda masa inkubasi penyakit terdapat pada perlakuan perendaman selama 60 menit $\left(\mathrm{S}_{4}\right)$ dengan varietas Blis $\left(\mathrm{P}_{3}\right)$.

5. Perlakuan varietas benih kentang dengan perendaman biopestisida Streptomyces sp. isolat $\mathrm{BSi}$ selama 60 menit $\left(\mathrm{S}_{4}\right)$ menghasilkan jumlah umbi per tanaman, jumlah umbi per petak, berat per umbi dan berat umbi per petak tertinggi. Varietas Blis $\left(\mathrm{P}_{3}\right)$ menghasilkan jumlah umbi per tanaman, jumlah umbi per petak, dan berat umbi per petak tertinggi. Adapun interaksi terbaik antara varietas Atlantik (P2) dengan lama perendaman biopestisida Streptomyces sp. isolat BSi selama 60 menit $\left(\mathrm{S}_{4}\right)$ dan varietas Blis $\left(\mathrm{P}_{3}\right)$ dengan lama perendaman biopestisida Streptomyces sp. isolat BSi selama 60 menit $\left(\mathrm{S}_{4}\right)$ menghasilkan berat umbi per petak tertinggi. 


\section{Saran}

Berdasarkan hasil penelitian tersebut perlakuan perendaman benih kentang dengan biopestisida Streptomyces sp. isolat BSi disarankan menggunakan waktu perendaman selama 60 menit. Perlu dilakukan penelitian lebih lajut untuk mengetahui senyawa yang dihasilkan oleh Streptomyces sp. serta meningkatkan virulensi dari Streptomyces sp.. Varietas yang paling baik digunakan di dataran medium yaitu varietas Blis. Perlu dilakukan penelitian lebih lanjut dengan cara aplikasi yang berbeda dan dilakukan lebih dari satu kali.

\section{DAFTAR PUSTAKA}

Adimihardja, A. (2008). Teknologi dan Strategi Konservasi Tanah dalam Rangka Revitalisasi Pertanian. Jurnal: Pengembangan Inovasi Pertanian, 1(2):105-124.

Aryantha,N.P., Lestari D. P., \& Pangesti N. P. D. (2005). Potensi Isolat Bakteri Penghasil IAA dalam Peningkatan Pertumbuhan Kecambah Hijau pada Kondisi Hidroponik. Jurnal Mikrobiologi Indonesia, 9(2)

Badan Pusat Statistik, (2014). Luas Panen, Produksi Dan Produktivitas Kentang Nasional.http://www.bps.go.id/tab_sub/view.php?kat=3\&tabel=1\&daftar= \&id. Diakses tanggal 1 November 2016.

Burnett F., \& Oxley S. (2010). Potatoe Storage Diseases. SAC Journal, University of Idaho, UK.

Hidayat Y, S. (2014). Karakteristik Morfologi Bbeberapa Genotipe Kentang (Solonum tuberosum L.) Yang Dibudidayakan Di Indonesia. Institut Pertanian Bogor. Bogor.

Hidayat, A. F. (2017). Respon Pemberian Pupuk Ponska dan Uji Teknik Aplikasi Agen Hayati Streptomyces sp. Dalam Mengendalikan Layu Fusarium Untuk Meningkatkan Produktivitas Tanaman Cabai. [Skripsi]. Mataram. Program Studi Agroekoteknologi Universitas Mataram.

Kawuri, R. (2010). Pemanfaatan Streptomyces Thermacarboxydus Untuk Mengendalkijan Penyebab Penyakit Busuk Daun Pada Lidah Buaya (Aloe Barbadenis Moll) Di Bali. Disertasi [Doctor]. Denpasar. Program Studi Ilmu Pertanian. Universitas Udayana.

Lehr N. A., S. D. Schrey., Hamp R., Tarkka M.T. (2008). Root inoculation with a forest soil Streptomycetes leads locally and systemically increase resistance against Phtopthora in Nurwey spruce. New Phytology. 177: 965-976.

Muthahanas I, Erna L. (2008). Skrining Streptomyces sp. Isolat Lombok Sebagai Pengendali Hayati Beberapa Jamur Patogen Tanaman. Jurnal CropAgo.1 (2).

Muthahanas I, Isnaini M. (2010). Pemanfaatan Streptomyces sp. isolat Lombok Sebagai Bioagen Untuk Mengendalikan Penyakit Layu Fusarium Pada Tanaman Tomat. [Laporan Penelitian]. Universitas Mataram. Mataram.

Nurainal, L. (2012). Taksonomi tanaman kentang. Diakses dari http://leniblogs.blogspot.com/2012/12/taksonomi-tanaman-kentang.html pada tanggal 30 Desember 2017 pukul 14.24 WIB.

Semangun, H. (2007). Penyakit Penyakit Tanaman Hortikultura edisi ke II. Gadjah Mada University Press: Yogyakarta.

Setiawati., W., Murtiningsih, Karyadi R., A.K. (2009). Meneropong Perkembangan OPT Kentang dalam Kurun waktu 10 tahun (1999 - 2008) dan Prediksi di masa depan. Prosiding Seminar Pekan Kentang Nasional Tahun 2008, tanggal 20 s.d. 21 Agustus 2008 di Lembang. Vol. 1. Puslitbang Hortikultura. Jakarta. 